DOI: $10.31073 / \mathrm{mivg} 201801-107$

Available (PDF): http://mivg.iwpim.com.ua/index.php/mivg/article/view/107

УДК 626.8: 303.732 .4

\title{
СИСТЕМНИЙ ПІДХІД ДО ОЦІНКИ ФУНКЦІОНУВАННЯ МЕЛІОРАТИВНИХ СИСТЕМ УКРӒ̈НИ
}

О.О. Дехтяр, канд. тех. наук

Інститут водних проблем і меліорації НААН, Київ, Україна; e-mail: oksana.dehtiar@gmail.com

\begin{abstract}
Анотація. У статті проаналізовано використания методів системного аналізу при дослідженні тенденцій та проблем, що існують у секторі зрочення та дренажу Украйни. Розкрито основні поняття та закономірності теорії систем та системного аналізу, ио мають вирішальне значення для управління техніко-технологічними та сочіально-економічними об 'єктами господарювання в меліораиії. Досліджено та проаналізовано основні чинники розвитку і специфіка існування меліоративних систем на сучасному етапі та встановлено основні закономірності їх функиіонування. Нинішній етап розвитку меліоративного землеробства в Украйні загострюеться рядом глобальних геополітичних викликів та потребує науково обгрунтованого підходу до розробки і впровадження виважених заходів з нароцування потенціалу існуючих зроиувальних та дренажних систем. Застосування в дослідженнях системного аналізу дає зиогу обтрунтувати необхідність комплексного підходу до використанна механізмів, що забезпечують узгоджене існування всіх складових елементів меліоративної системи та встановити низку закономірностей їх функиіонування. Встановлено, иоо радикальних змін потребус механізм управління водними ресурсами і меліорацісо земель, удосконалення законодавчої і нормативно-методичної бази та створения умов для залучення інвестицій на відновлення і модернізачію інженерної інфраструктури для досягнення сталого розвитку аграрного сектора економіки Украйни.
\end{abstract}

Ключові слова: меліоративні системи, розвиток, функиіонування, системний аналіз, закономірності

Актуальність. Меліоративні системи $\epsilon$ складними природно-техніко-технологічними об'єктами, які нерозривно пов'язані як із основними законами природи, так і $з$ загальними законами розвитку технічних систем, діяльність яких можна описати за допомогою стохастичних процесів. Закони розвитку техніки визначають для окремих технічних систем об'єктивно існуючі зв'язки, особливості та тенденції розвитку для прогнозування процесів створення нових та покращення вже існуючих систем. Водночас недоліки попереднього етапу функціонування системи стають критеріями розвитку для наступного покоління 3 інноваційними техніко-технологічними рішеннями $[1,2]$.

В Україні через причини політичного, економічного та соціального характеру потенціал раніше побудованого потужного водогосподарського комплексу, що забезпечував зрошення на площі 2,65 млн. га, а осушення на площі 3,3 млн. га, використовується неефективно. Істотно скоротились площі зрошуваних земель: фактично поливається менше 500 тис. га, а двостороннє водорегулювання здійснювалось на площі близько 250 тис. га, що становить $20 \%$ наявних площ зрошення та менше $10 \%$ наявних площ дренажу [3-5].
Визначальним фактором є також глобальні кліматичні зміни, наслідки яких в Україні за останні роки все відчутніші і проявляються у зростанні температури повітря і збільшенні сухої та дуже сухої території.

Проведення меліоративних заходів сприяє зменшенню дефіциту природного вологозабезпечення та ефективному регулюванню вологості грунту у вегетаційний період для отримання заданого рівня врожайності сільськогосподарських культур у нових кліматичних умовах.

Складність, масштабність та різноманітність проблем, існуючих на сьогодні у водогосподарській галузі, зокрема у секторі зрошення та дренажу, потребус широкого використання методів системного аналізу при проведенні досліджень та визначенні шляхів і напрямків розв'язання цих проблем.

Аналіз останніх досліджень і публікацій. Оцінюванню різних аспектів функціонування меліоративних систем з використанням методів системного аналізу присвячено багато наукових досліджень [1, 2, 6-13]. Визначаючи вагомість наявних розробок слід відзначити, що на сьогодні ці методи недостатньо використовуються в меліорації через складність та суперечливість питань, що потребують відпо- 
відей, часто виокремивши одну з проблем і не охоплюючи всього комплексу. Слід зазначити, що різні науковці, представники водогосподарських організацій, органів місцевого самоврядування, сільгоспвиробники неоднозначно та суб'єктивно трактують мету, цілі та шляхи сталого розвитку меліоративного землеробства. Тому, у зв'язку з необхідністю адаптації аграрної галузі економіки України до сучасних умов ринкового та природного середовища існує потреба в науково-методичних системних підходах для всебічної оцінки потенціалу меліоративної галузі 3 визначенням основних закономірностей функціонування та стратегічних напрямків сталого розвитку.

Мета досліджень - аналіз тенденцій сучасного етапу функціонування зрошувальних та дренажних систем України з використанням методів системного аналізу i встановлення основних закономірностей функціонування меліоративних систем.

Викладення основного матеріалу. Для ефективного управління складними і різноманітними процесами функціонування меліоративних систем потрібен спеціалізований методологічний підхід. Системний аналіз i $\epsilon$ саме такою сукупністю методів, які допомагають чітко поставити цілі, вірно сформулювати завдання і правильно його виконати. При проектуванні, будівництві та експлуатації меліоративних систем виникають ситуації, які характеризуються невизначеністю, наявністю факторів, що нерідко призводять до нераціонального використання земельних, водних, фінансових, трудових ресурсів, неузгодженості в роботі окремих елементів системи землевласник - водокористувач - водогосподарські організації - природні ресурси.

Системний аналіз дозволяє домогтися сумарної ефективності функціонування системи, не допускаючи щоб́ приватні цілі i інтереси підсистем знижували загальний результат, особливо у випадках, коли цілі окремих підсистем часто суперечливі або навіть взаємовиключні. Оптимальні рішення для окремої підсистеми не завжди є оптимальними для системи загалом.

Згідно 3 основними положеннями системного аналізу $[1,2,6-8,11,13]$ меліоративна система може розглядатися як багатокомпонентна. Її загальний стан та кожного 3 об'єктів залежить від багатьох факторів, які змінюються 3 часом. Середовище, у якому знаходиться меліоративна система, це сукупність усіх об'єктів, зміна властивостей яких впливає на систему, та об'єкти, чиї власти- вості змінюються в результаті діяльності системи. Для меліоративних систем поряд iз природним середовищем існує створене людиною технічне середовище, яке містить у собі гідротехнічні споруди, насосно-силове обладнання, дощувальну техніку тощо, а також економічне, політичне, інформаційне та соціальне середовища.

Вивчення закономірностей функціонування зрошувальних та дренажних систем на сучасному етапі розвитку дозволяє уточнити та покращити уявлення про досліджувану систему, уяснити загальну поточну ситуацію, стан системи, визначити процеси, які там протікають та розробити шляхи та механізми подальшого її удосконалення.

Головний критерій розвитку меліоративної системи - ефективність ії діяльності, тобто сукупність впливу системи в цілому та iii підсистем на кількість і якість отриманої сільськогосподарської продукції, враховуючи використані одночасно природні, енергетичні, фінансові та трудові ресурси. Тобто меліоративна система включає в себе не тільки процеси водоподачі, водовідведення, транспортування води до поля, а й підсистеми прийому, обробки інформації на вході та виході, а також підсистеми прийняття рішень, планування діяльності і подальшого розвитку $[6,11]$.

Для забезпечення сталого розвитку меліоративної системи важливим є узгодженість у роботі всіх підсистем та їх елементів задля досягнення синергізму - одночасного функціонування окремих, але взаємопов'язаних елементів та частин, що забезпечать більш високу загальну ефективність ніж сумарна ефективність окремих частин, що працюють самостійно. Так впровадження нових технологій вирощування сільськогосподарських культур, високопродуктивних сортів та гібридів, науково обгрунтованих сівозмін, покрашення екологічного стану водних об'єктів та грунтів, технічного стану каналів, модернізація насосно-силового обладнання, внесення змін до діючого законодавства, розробка концепцій та стратегій розвитку, створення організацій водокористувачів, реформування системи управління галуззю все це матиме значно більший ефект при впровадженні складових разом, ніж від використання елементів окремо. Слід визнати, що при виокремленні із загальної сукупності найбільш значимих компонентів можна сформувати функціонально результативну сукупність для виконання пріоритетних завдань.

У загальному вигляді існують такі основні закономірності функціонування систем, 
що характеризують принципові особливості побудови, функціонування та розвитку складних систем $[1,2,6,7,11,12]$ :

- розвитку (історичність, самоорганізація);

- взаємодії частини і цілого (цілісність, прогресуюча систематизація, прогресуюча факторизація, адитивність);
- ієрархічної впорядкованості (комунікативність, ієрархічність);

- здійсненності (закон необххідного різноманіття, еквіфінальність, потенційна здійсненність) (рис. 1).

В умовах існуючих глобальних викликів та загроз важливо адаптувати ці основні закономірності до сучасних реалій сьогодення.

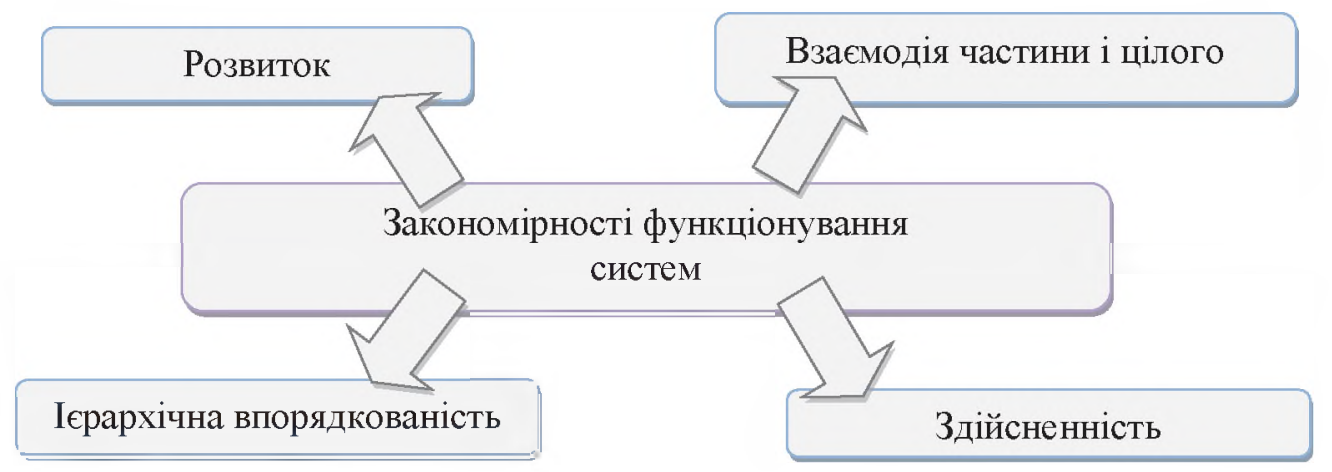

Рис. 1. Основні закономірності функціонування систем

Закономірності розвитку. Історичність. Кожна система проходить етапи зародження, становлення, удосконалення та занепаду. Цю закономірність можна враховувати не тільки пасивно фіксуючи стан функціонування, а й використовувати для попередження руйнування та при розробці механізмів та способів реконструкції, модернізації меліоративних систем, для їх розвитку у новій якості.

В Україні розквіт та становлення меліоративних систем припадає на минуле століття, коли проектувались та будувались великі меліоративні системи: Каховська, Інгулецька, Краснознаменська, Північно-Рогачицька, Сірогозька, зрошувальні системи Північно-Кримського каналу, Ірпінська, Трубізька, Остерська, Замисловицька, Берегівська осушувально-зволожувальні системи та інші. Останнім часом на фоні глобальних змін клімату та загальної економічної кризи функціонування цих систем здійснюється неналежним чином. Це призвело до занепаду підсистем та елементів меліоративної системи, виникнення кризової ситуації, головними чинниками якої $є$ :

- значне погіршення технічного стану об'єктів інженерної інфраструктури;

- зменшення кількості дощувального обладнання та відсутність коштів у водокористувачів на оновлення та поповнення парку дощувальних машин;

- порушення технологічної цілісності меліоративного землеробства;

- недосконалість існуючого законодавства:
- невідповідність існуючої системи управління новим ринковим умовам господарювання;

- різке зростання вартості електроенергії для подачі води на зрошення;

- відсутність бюджетного фінансування та неможливість залучення інвестицій на відновлення та модернізацію меліоративних систем.

Проте сьогодні, коли Уряд України взяв курс на здійснення реформ системи управління водогосподарською галуззю і в результаті будуть створені умови для залучення інвестицій для відновлення та модернізації меліоративних систем, збільшення площ зрошення, 3'являються перспективи покращення функціонування i поступового переходу із стадії занепаду у стадію сталого розвитку.

Самоорганізація - це здатність системи самостійно підтримувати чи вдосконалювати рівень своєї організації при зміні зовнішніх або внутрішніх умов іiі існування, переходити на новий ступінь розвитку, здійснювати діяльність з урахуванням минулого досвіду $[6,8,11]$. Самоорганізація системи здійснюється в результаті взаємодії випадковості й необхідності та пов'язана 3 переходом від нестійкості («біфуркації») до стабільності, стійкого стану («аттрактора»). Стан стабільності $\epsilon$ обов'язковою умовою існування й функціонування системи, перехід до нової системи та iii розвиток $є$ неможливим без виведення системи із стійкого стану $[10,12]$. 
Неефективний стан функціонування меліоративних систем сьогодні - це черговий етап самоорганізації, коли управління, ресурси, власність перерозподіляються, змінюються взаємовідносини. Рушійними силами цього процесу $\epsilon$ наростаючі суперечності між відсутністю фінансових можливостей i нездатністю сільгоспвиробників відновлювати зрошення на належному рівні та неможливістю отримання високих та стабільних врожаїв без поливів, особливо у південних регіонах України.

Сучасна криза $\epsilon$ насамперед інституційною, оскільки система управління водогосподарською галуззю, створена ще за часів індустріальної економічної системи, перебуває у кризовому стані, не відповідає сьогоденню та не адаптована до можливостей ринкової економіки. Похідними самоорганізації $є$ управлінські та організаційні відносини. Система не може ефективно реалізовуватися та функціонувати без самоорганізації у сферах політики та державного управління, тому що зміни до існуючого законодавства, нові закони, що забезпечують інституціональне середовище для розвитку меліорації, створюються саме на урядовому рівні.

Проведення реформування системи управління дасть змогу підвищити ефективність функціонування, упорядкувати взаємозв'язки між ії елементами та підсистемами за рахунок не тільки залучення додаткових фінансових ресурсів на відновлення та модернізацію зрошувальних та дренажних систем, а і за рахунок власного розвитку, впроваджуючи інноваційні технології дозволить розкрити іï внутрішній потенціал та перейти на самоокупність.

Закономірності взасмодії частини i цілого. Цілісність - закономірність, що виявлясться в системі у вигляді появи у неї нових властивостей, що відсутні у окремих ії елементів [6, 7]. Закономірність цілісності, 3 одного боку, не $€$ простою сумою властивостей складових її елементів; з іншого - властивості цілої системи $\left(Q_{s}\right)$ залежать від властивостей складових ії частин $\left(q_{i}\right)$. До того ж, об'єднані в систему елементи, як зазвичай, втрачають частину своїх властивостей, які мають поза системою, тобто система як би погіршує їх; але, з іншого боку, елементи, потрапивши у систему, можуть придбати нові властивості, що сприятимуть удосконаленню існуючої системи $[7,10]$.

$$
Q_{S} \neq \sum_{i=1}^{n} q_{i}(1)
$$

$$
Q_{S}=f\left(q_{i}\right)
$$

Загалом меліоративну систему неможливо вивчити, досліджуючи лише складові частини і не враховуючи взаємодії між ними, не розглядаючи як сукупність взаємопов'язаних елементів: зміни клімату, стан грунтів, водні та енергетичні ресурси, сівозміни, техніко-технологічні складові, інституційні, правові, управлінські рішення, інформаційне забезпечення та ін. Так заміна насосно-силового обладнання, відновлення протифільтраційного облицювання зрошувальних каналів, використання енергозберігаючих технологій, зміна структури сівозмін, зрошувальних норм, поява нових суб' єктів господарювання, зміни в управлінні можуть суттєво вплинути на якість функціонування всієі меліоративної системи. Оптимізація режимів окремих технологічних процесів без врахування їх взаємодії з іншими процесами може призвести до неефективного розвитку системи загалом.

Використання сучасного високопродуктивного та енергоощадного дощувального обладнання дозволяє отримати такі показники якості як точність видачі поливної норми, якість і рівномірність подачі води на зрошення, оптимальну для даних грунтових умов інтенсивність дощу з врахуванням фізіологічної потреби рослин у воді, що сприяє покрашеному регулюванню вологості грунту та збільшенню виходу сільгосппродукції.

Унаслідок неефективних рішень, прийнятих Урядом після розпаду Радянського Союзу, зруйнувалась цілісність всього меліоративного комплексу, спричинена розпаюванням земель, подрібненням розмірів земельних ділянок та збільшенням кількості землекористувачів, що призвело до погіршення технічного стану елементів меліоративної мережі, а в багатьох випадках до їх руйнування та знищення. Саме ефективне реформування орієнтоване на інноваційне управління водогосподарською галуззю має забезпечити появу у меліоративних систем нових властивостей. Послідовна реалізація цих процесів дозволить накопичити критичну масу прогресивних перетворень для якісного зростання ефективності водоподачі, водорозподілу та водовідведення, та досягнення сталого функціонування всієї меліоративної системи.

Прогресуюча факторизація (ізоляція) i прогресуюча систематизація. Ці закономірності ввів американський вчений А. Холл [8]. Прогресуюча факторизація це прагнення системи до стану з усе більш незалеж- 
ними елементами. Розрізняють два види цієї закономірності:

- розпад системи на незалежні частини 3 втратою загальносистемних властивостей.

- зміни в напрямку зростаючого поділу на підсистеми зі збільшенням ї самостійності або в напрямку зростаючої диференціації функцій, шо характерно для систем, які еволюціонують та розвиваються.

Прогресуюча систематизація це прагнення системи до більшої цілісності, посилення існуючих раніше зв'язків між частинами системи, появи та розвитку нових зв'язків між раніше не пов'язаними між собою елементами або підсистемами, додавання у систему нових елементів. У меліоративних системах це, наприклад, виникнення нових відносин між сільгоспвиробниками, структуруванні споживачів води в об'єднання організації водокористувачів для управління, експлуатації та технічного обслуговування внутрішньогосподарської мережі; утворення великих агропромислових підприємств, розробка та внесення змін до законів для створення ефективної законодавчої бази для імплементації нових управлінських структур та визначення їх функцій, зміна політики відносно інвестицій у водне господарство, необхідних для розвитку зрошуваного землеробства, поява сучасних інформаційних технологій.

Закономірності ієрархічної впорядкованості систем характеризує взаємодію системи 3 їі оточенням - 3 навколишнім середовищем, надсистемою та підлеглими ій підсистемами $[6,12]$. Більш високий ієрархічний рівень об'єднує елементи нижчого рівня і впливає на іх функціонування. У результаті нижчі члени ієрархії набувають нових властивостей, відсутніх у них при ізольованому стані. Меліоративна система - це складова великої природно - техногенної системи, яка входить у якості підсистеми у водогосподарську, сільськогосподарську, економічну, соціальну системи країни.

Гетерархія. На відміну від ієрархії, що припускає відносини залежності, гетерархія (запропонована Д. Старком) [12,15, 16] передбачає не вертикально підпорядковані зв'язки між елементами системи, а горизонтальний поділ системних функцій між цими елементами. Водночас кожна підсистема залучається до пошуку інноваційних рішень, а система загалом $\epsilon$ більш гнучкою до адаптації в умовах нестабільності зовнішнього середовища. Отже, гетерархія - відповідь на виклики, породжені сучасним підвищенням невизначеності, пов'язаним із стрімкою зміною технологічних процесів, політичною нестабільністю в нашій країні.

Тобто, якщо ієрархія включає стосунки залежності, а ринок має на увазі незалежність, гетерархія передбачає стосунки взаємозалежності, і саме впровадження гетерархії має на меті удосконалення інституційного механізму налагодження ефективності функціонування меліоративної системи з урахуванням потреб та узгодженням інтересів всіх зацікавлених сторін. Важливим $є$ консолідація зусиль державних органів влади, водогосподарських, експлуатаційних організацій, сільгоспвиробників, всіх зацікавлених сторін для координації дій в рамках реалізації сумісних зусиль та заходів з підтримки сектора зрошення та дренажу. При цьому першочергове значення має створення правових та організаційних умов, проведення структурних перетворень та реформування системи управління галуззю. Недосконалість законодавства у сфері меліорації земель, у питаннях земельних відносин, податковій, тарифній, соціальній сферах створює нездоланні бар'єри для успішного вирішення комплексу екологічних, економічних та соціальних проблем.

Комунікативність. Меліоративна система не ізольована від інших систем, вона пов'язана безліччю комунікацій 3 навколишнім природним середовищем, інформаційними, управлінськими підсистемами, містить надсистеми більш високого порядку - агропромисловий комплекс, водогосподарську галузь та ін., що задає вимоги і обмеження даній системі, елементам або підсистемам, системам одного рівня 3 даною. Ця закономірність проявляється між рівнями ієрархії системи i в результаті кожен рівень ієрархічної впорядкованості має складні взаємини 3 вищим і нижнім рівнями

Закономірності здійсненності систем. Еквіфінальність характеризує ніби граничні можливості системи, здатність на відміну від стану рівноваги в закритих системах досягати рівня, котрий залежить від часу конкретного стану та не залежить від початкових умов і визначається виключно параметрами системи $[6,12]$. Ця закономірність змушус визначити граничні можливості створюваних організаційних систем управління галузями, регіонами, державою.

Закон «необхідної різноманітності» сформулював У.Р. Ешбі. [12, 13]. Створюючи систему, здатну впоратися 3 вирішенням проблеми, яка має певну різноманітність, потрібно забезпечити шоб система мала ще 
більшу різноманітність методів вирішення, ніж різноманітність вирішуваної проблеми, тобто володіла б методологією, могла запропонувати нові методи вирішення проблеми. Отже, різноманітність системи управління повинна бути більше різноманітності об'єкта управління. Використання цього закону при розробці та вдосконаленні систем управління допомагає виявити причини недоліків, які 3'являються в системі, та знайти шляхи підвищення ефективності управління.

Закономірність потенційної ефективності. Флейшман Б.С. пов'язав складність структури системи зі складністю їі поведінки; запропонував кількісні вирази граничних законів надійності, стійкості, керованості та інших якостей систем, які визначаються як ймовірність досягнення мети при обмежених ресурсах (часу, енергії і т.), та показав, що на їх основі можна отримати кількісні оцінки здійсненності систем 3 точки зору тісї чи іншої якісної характеристики - граничні оцінки життєздатності і потенційної ефективності складних систем [14].

Закономірності функціонування меліоративних систем визначають загальну ситуацію розвитку та пов'язують в єдине ціле фактори проявів конкретних процесів, що проходять у системі залежно від природних умов навколишнього середовища, існуючих проблем та загальної ситуації, що складається в конкретному регіоні і в країні загалом.

Отже, використання системного підходу шодо вивчення поточної ситуації функціонування сектора зрошення та дренажу в умовах змін клімату та господарювання, оцінки техніко-технологічного стану інженерної інфраструктури меліоративних систем, існуючої системи управління та державної політики в галузі меліорації дозволило встановити такі закономірності функціонування меліоративних систем України:

- глобальні кліматичні зміни, які спричинили зростання посушливості клімату, зумовили необхідність поширення зони застосування систем зрошення на північ країни i таким чином в гумідній зоні для ефективного регулювання водного режиму доцільно використовувати системи 3 можливістю додаткового зволоження;

- висока енергоємність процесів водоподачі та водорозподілу в умовах постійного підвищення тарифів на електроенергію разом 3 надмірними втратами води при транспортуванні обумовлюють підвищення вартості води для кінцевого споживача, що впливає на собівартість сільськогосподарської продукції та стримує сталий розвиток сектора зрошення в Україні;

- підвищення ступеня використання наявного потенціалу зрошувальних та осушувальних систем потребує розширення площ зрошення та водорегулювання, що можливо лише за формування відповідної державної політики, проведення інституційної реформи системи управління водними ресурсами, удосконалення законодавчої бази шляхом внесення змін та доповнень до існуючого законодавства та розроблення нових законодавчих актів і зрештою, створення сприятливих умов для залучення інвестицій у розвиток водогосподарсько-меліоративного комплексу.

Висновки. Нинішній етап розвитку меліоративного землеробства в Україні загострюється через глобальні виклики та потребує науково обгрунтованого підходу до розробки i впровадження виважених заходів 3 нарошування потенціалу існуючих зрошувальних та дренажних систем. Застосування в дослідженнях системного аналізу дає змогу забезпечити узгоджене існування всіх складових елементів меліоративної системи та встановити ряд закономірностей їх функціонування для подальшого розвитку.

Радикальних змін потребує механізм управління водними ресурсами, удосконалення законодавчої і нормативно-методичної бази та створення умов для залучення інвестицій на відновлення і модернізацію інженерної інфраструктури для досягнення сталого розвитку аграрного сектора економіки України.

\section{Бібліографія}

1. Штепа Б.Г Методы системного анализа в мелиорации и водном хозяйстве. Ленинград: Гидрометизат. 1983. $261 \mathrm{c}$.

2. Рекс Л.М. Системные исследования мелиоративных проиессов и систем. Москва: Аслан. 1995. $192 \mathrm{c}$.

3. Концепція відновлення та розвитку зрошення у південному регіоні України Ромащенко М.I. Київ: ЦП Компринт, 2014. 28 c.

4. Меліорація грунтів (систематика, перспективи, інновачії): колективна монографія Балюк С.А. та ін. Херсон: Грінь Д. 2015. 668 с. 
5. Romashchenko M., Dekhtiar O. (2016). Irrigation Reform in Ukraine: Organizational and Legal Aspects. // Water management in a changing World: Role of Irrigation in Sustainable Food Production:2nd World Irrigation Forum. Chiang Mai, Thailand.W.1.3.01. 11 p.

6. Берталанфи Л. фон. Общая теория систем - Критический обзор. Москва: Прогрес. 1969. $28 \mathrm{c}$

7. Рузавин Г. И. Методология научного исследования.Москва:Мысль, 1999. 282 c.

8. Холл А. Опыт методологии для системотехники. Москва.Сов. радио, 1975.

9. Шкодіна І.В. Сучасні тендениії самоорганізації світової економічної системи. 2012. URL: file://C:/Users/user/Downloads/EkUk_2012_9_8.pdf

10. Афанасьєв В. Г. Проблема иілісності у філософії та біологї̈. Москва: Думка. 1984.

11. Волкова В. Н. Теория систем и системный анализ в управлении организациями. Москва: Финансы и статистика. 2012. 848 c.

12.Блюмин A.M. Теория системи системный анализ. URL: knigainformatika.narod.rusdisciplins teoria... SA.doc. $-86 \mathrm{c}$.

13.Динкевич А. Закономерности экономического развития (проблемы методологии) Экономист. 2001. №11. C. 71-80.

14. Флейиман Б. С. Элементы теории потенциальной эффективности сложных систем. Москва. Смоленск. 2008.

15. Чернышев М. К., Гаджев М. К. Математическое моделирование иерархических систем. Москва. Наука. 1983.

16. Stark D. Ambiguous Assets for Uncertain Environments: Heterarchy in Postsocialist Firms. URL: https:/ecsoc.hse.ru/en/2001-2-2/26593183.html.

\section{References}

1. Shtepa, B.G. (1983). Metody systemnoho analyza v melyoratsyy y vodnom khoziaistve [Methods of system analysis in land reclamation and water management]. Lenynhrad: Hydrometyzat. [in Russian].

2. Reks, L.M. (1995). Sistemnyye issledovaniya meliorativnykh protsessov i system [System research of meliorative processes and systems]. Moskva. [in Russian].

3. Romashchenko, M.I. (2014). Kontseptsiia vidnovlennia ta rozvytku zroshennia u pivdennomu rehioni Ukrainy [Concept of Irrigation Recovery and Development in the Southern Region of Ukraine] Kyiv. [in Ukrainian ]

4. Baliuk, S.,Truskavetskyi, R.S., Romashchenko, M.I. (2015). Melioratsiia hruntiv [Soil melioration] Kherson. [in Ukrainian].

5. Romashchenko, M.I., Dekhtiar O.O. (2016). Irrigation Reform in Ukraine: Organizational and Legal Aspects. / Water management in a changing World: Role of Irrigation in Sustainable Food Production:2nd World Irrigation Forum. Chiang Mai, Thailand, W. 1.3.01. 11r.

6. Bertalanfy, L. fon. (1969). Obshchaia teoryia system - Krytycheskyi obzor. [General System Theory - A Critical Review]. Moskva: Prohres. [in Russian].

7. Ruzavyn, H. Y. (1999). Metodolohyia nauchnoho yssledovanyia. [Methodology of scientific research]. Moskva: Musl. [in Russian].

8. Kholl, A. (1975). Opyt metodologii dlya sistemotekhniki [Experience in methodology for system engineering]. Moskva: Sov. Radio. [in Russian].

9. Shkodina, I.V. (2012). Suchasni tendentsï̈ samoorganizatsï̈ svitovö̈ ekonomichnoï sistemi. [Modern tendencies of self-organization of the world economic system] Retrieved from file://C:Users/user/Downloads/EkUk_2012_9_8.pdf. [in Russian].

10.Afanasev, V. G. (1984). Problema tsilisnostiv filosofii ta biologii [The problem of integrity in philosophy and biology]. Moskva: Dumka. [in Russian].

11. Volkova, V.N. (2012). Teoriya sistemi sistemnyy analiz v upravlenii organizatsiyami. Spravochnik Theory of Systems and System Analysis in the Management of Organizations. Handbook] Moskva: Finansy i statistika. [in Russian].

12.Blyumin, A.M. Teoriya sistemi sistemnyy analiz. (2006). [System theory system analysis]. Retrieved from knigainformatika.narod.ruidisciplins/teoria. SA.doc. [in Russian].

13.Dinkevich, A. Zakonomernosti ekonomicheskogo razvitiya (problemy metodologii) [The laws of economic development (problems of methodology)] Moskva: Ekonomist. 2001, 11. [in Russian]. 
14.Gryaznova, A.G., Dumnoy, N.N., Yudanova, A.Yu. (2005). Ekonomicheskaya teoriya. Ekspresskurs: ucheb. posob. [Economic theory. Express course: study. way]. Moskva: KNORUS. [in Russian].

15. Fleyshman, B. S. (2008). Elementy teorii potentsialnoy effektivnosti slozhnykh sistem. [Elements of the theory of potential efficiency of complex systems]. Moskva. Smolensk. [in Russian].

16.Chernyshev, M. K.. Gadzhiyev, M. K. (1983). Matematicheskoye modelirovaniyeiyerarkhicheskikh sistem. [Mathematical modeling of hierarchical systems]. Moskva: Nauka. . [in Russian].

17.Stark, D. Ambiguous Assets for Uncertain Environments: Heterarchy in Postsocialist Firms. [Ambiguous Assets for Uncertain Environments: Heterarchy in Postsocialist Firms]. Retrieved from: https://ecsoc.hse.ru/en/2001-2-2/26593183.html.

Дехтяр О.A.

\section{Системный подход к оценке функционирования мелиоративных систем Украины}

В статье проанализировано использование методов системного анализа при исследовании тенденций и проблем, существуюиих в секторе оромения и дренажса Украины. Раскрыты основные понятия и закономерности теории систем и системного анализа, имеющих определяющее значение для управления технико-технологическими и сочиально-экономическими объектами хозяйствования в мелиорачии. Исследованы и проанализированы основные факторы развития и специфика существования мелиоративных систем на современном этапе и установлены основные закономерности их функиионирования. Нынечний этап развития мелиоративного земледелия в Украине обостряется рядом глобальных геополитических вызовов и требует научно-обоснованного подхода к разработке и внедрению взвешенных мер по наращиванию потенциала существующих оросительных и дренажных систем. Применение в исследованиях системного анализа позволяет обосновать необходимость комплексного подхода $к$ использованию механизмов, обеспечивающих согласованное существование всех составляющих элементов мелиоративной системы и установить ряд закономерностей их функиионирования. Установлено, что радикальных изменений требует механизм управления водными ресурсами и мелиорацией земель, совериенствование законодательной и нормативно-методической базы и создание условий для привлечения инвестиций на восстановление и модернизаиию инженерной инфраструктуры для достижения устойчивого развития аграрного сектора экономики Украины.

\section{System approach to the estimation of the operation of Ukrainian reclamation systems}

The article analyzes the use of methods of system analysis in studying the trends and problems that exist in the irrigation and drainage sector in Ukraine. The basic concepts and regularities of the theory of systems and system analysis, which are decisive for the management of techno-technological and socio-economic objects of management in land reclamation, are revealed. The main factors of development and specificity of the existence of reclamation systems at the present stage are investigated and analyzed and the main regularities of their functioning are established. The current stage in the development of land reclamation agriculture in Ukraine is exacerbated by a number of global geopolitical challenges and requires a scientifically sound approach to the development and implementation of prudent measures to build the capacity of existing irrigation and drainage systems. Application in system analysis studies makes it possible to substantiate the necessity of an integrated approach to the use of mechanisms that ensure the coherent existence of all components of the reclamation system and establish a number of patterns of their functioning. It has been established that radical changes require the mechanism of water resources management and land reclamation, improvement of the legislative and normative-methodological base and creation of conditions for attraction of investments for restoration and modernization of engineering infrastructure in order to achieve sustainable development of the agrarian sector of the Ukrainian economy. 